\title{
ANALYSIS OF SODIUM TETRABORATE DECAHYDRATE (BORAX) ON TOFU AT TRADITIONAL MARKETS IN SURAKARTA, CENTRAL JAVA
}

\author{
Ulya Khoirunnisa' Atin, Rezania Asyfiradayati \\ Faculty of Health Sciences, Universitas Muhammadiyah Surakarta
}

\begin{abstract}
Background: Borax (or sodium tetraborate) is a naturally occurring alkaline compound that is a precursor in the manufacture of boric acid. Used as a preservative, buffer, antiseptic and fungicide. It is also used as a food additive. Borax has the toxicity to humans, including reproductive and developmental toxicity, neurotoxicity, and nephrotoxicity. The degree of borax toxicity depends on the dose or concentration that the human received. This study aimed to describe sodium tetraborate decahydrate (borax) level in tofu at traditional markets.

Subjects and Method: A descriptive cross sectional study was conducted at Gede, Nongko, Kadipolo, Sidodadi, and Jongke traditional markets in Surakarta, Central Java. A sample of 14 tofu was selected randomly. The study variable was sodium tetraborate decahydrate (borax). Sodium tetraborate decahydrate level was assessed qualitatively using turmeric test kit.

Results: The maximum level of sodium tetraborate decahydrate that is allowed to be in food is $1.6 \mathrm{ppm}$. All sample was well below the allowable threshold. Sodium tetraborate decahydrate content in tofu products varies from the highest at $0.075 \mathrm{ppm}$ to the lowest at $0.03 \mathrm{ppm}$.

Conclusion: Tofu products sold in Surakarta traditional markets are safe for consumption.

Keywords: soybean tofu, sodium tetraborate decahydrate, borax, allowable threshold, traditional markets

\section{Correspondence:}

Ulya Khoirunnisa' Atin. Masters Program in Public Health, Universitas Sebelas Maret. Jl. Ir. Sutami 36A, Surakarta 57126, Central Java. Email: ulyakhns9@gmail.com. Mobile: +6282325918686 .
\end{abstract}

